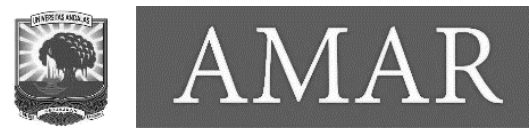

AMAR (Andalas Management Review)

Vol. 4, No. 1 (2020) 1-17

The Management Institute, Faculty of Economics, Universitas Andalas

ISSN (Print) 2476-9282 | ISSN (Online) 2548-155X

\title{
Analisis Faktor-Faktor yang Mempengaruhi Minat Kunjungan Berulang Wisatawan Milenial ke Bukittinggi
}

\author{
Heru Aulia Azmana, Yesi Elsandra ${ }^{b}$ \\ a,b Program Studi Manajemen Universitas Dharma Andalas, heruaulia@yahoo.com
}

\begin{abstract}
This study aims to determine the factors that influence the interest of millennial tourists repeatedly visit Bukittinggi. The object of this research is millennial tourists who visit Bukittinggi. The number of research samples was 96 people with a purposive sampling technique. The types of data used in this study are primary data and secondary data. Primary data comes from the opinion of each research sample using a questionnaire, to find out the response of the research sample regarding the influence of the Push factor and the Pull factor on the interest in repeated visits of millennial tourists. Meanwhile, secondary data comes from previous journals, books, internet media, and annual reports. The primary data obtained is then analyzed by testing with multiple linear regression analysis techniques. The results showed that push factors and pull factors had a significant positive effect on repeated visits of millennial tourists to Bukittinggi.
\end{abstract}

Key Words: push factor, pull factor, interest in repeat visits, millennial tourists

\section{PENDAHULUAN}

Beberapa tahun belakangan, muncul tren baru di dunia traveling dimana mayoritas pelaku kegiatan traveling adalah para kaum muda atau dikenal dengan generasi millennial. generasi milenial secara terminology pertama kali dicetuskan oleh dua pakar sejarah dan penulis Amerika, William Straus dan Neil Howe. Menurut mereka generasi milenial mewakili mereka yang lahir mulai dari tahun 1980 hingga setelahnya. ( dikutip dari Parhusip (2018))

Survei yang diadakan Topdeck Travel kepada 31.000 orang dari 134 negara berbeda, sebanyak 88 persen menyatakan telah menjelajah ke luar negeri sampai tiga kali dalam setahun dan 94 persennya merupakan rentang usia 18-30 tahun. Orang-orang muda dikatakan lebih tertarik untuk traveling ke luar negeri dibanding orang yang lebih tua. PBB bahkan mengatakan bahwa 20 persen dari seluruh wisatawan dunia merupakan mereka yang masih muda, para 
kaum milenial. Mereka jauh lebih tertarik traveling sebanyak-banyaknya ketimbang generasi yang lebih tua. Tak pelak hal tersebut turut membantu meningkatkan pendapatan negara sebanyak 180 dolar per tahun, dan terus meningkat sejak 2007 (Topdeck Travel,2019). Melihat potensi yang besar ini sudah seharusnya disikapi secara serius oleh pengelola wisata karena mereka memberikan implikasi ekonomi yang sangat besar bagi daerah tujuan wisata.

Tentunya dengan mengidentifikasi motivasi dan bentuk kunjungan wisata milenial ini akan dapat membantu pengelola destinasi wisata untuk menyiapkan strategi yang pas untuk merayu generasi milenial tersebut untuk mengunjungi objek wisata mereka secara berulang. Beberapa literatur terdahulu menjelaskan bahwa hampir semua wisatawan milenial memilih destinasi wisata dari mulut ke mulut dan mereka bagikan ke media sosial, selain itu hampir 31 \% wisatawan milenial berwisata secara mendadak dan $21 \%$ dari mereka rela berpenghasilan kecil asal sering bepergian sekalian bekerja.(WYSE,2016). Selain itu hasil penelitian Parhusip (2018) menemukan fakta bahwa hampir 73 \% wisatawan milenial yang berkunjung ke Bali mengalokasikan pendapatannya untuk kepentingan travelling dibandingkan untuk kebutuhan materialistis. Adapun motivasi utama mereka melakukan kunjungan wisata didominasi oleh motivasi pendorong berupa novelty dan knowledge seeking, sedangkan faktor penarik didominasi oleh safety, cleanliness dan variety of attraction. Temuan ini tentunya sangat menarik untuk di eksplorasi lebih jauh pada destinasi wisata lainnya untuk mengeneralkan hasil yang sudah ditemukan sebelumnya.

Kota Bukittinggi sebagai primadona wisata di Sumatera Barat harus siap dengan strategi yang tepat dalam menangkap arus kunjungan wisatawan milenial dengan segala motivasi dan perilakunya yang sangat unik. Sebagai kota dengan positioning yang kuat pada aspek pariwisata, perdagangan dan jasa, Kota Bukittinggi selalu menjadi magnet bagi pendatang untuk mencari kehidupan di Kota yang juga terkenal dengan udaranya yang sejuk. Tak heran jika kepadatan penduduknya lebih padat dibandingkan dengan kota-kota lainnya di Sumatera Barat. Kepadatan penduduk berbanding luas wilayah Kota Bukittinggi mencapai 4.858 orang setiap kilometer persegi. Luas Kota Bukittinggi yang hanya 0,06 persen dari luas provinsi Sumatera Barat memiliki jumlah penduduk berjumlah 122.621 jiwa. Dari jumlah tersebut, 97,45 persen diantaranya beragama Islam ( Kota Bukittinggi dalam Angka,2019). Filosofi adat bersandi syara' dan syara' bersandi kitabbullah menjadi tuntunan bagi masyarakat dalam berkehidupan sosial. 
Kearifan lokal yang dimiliki ini menjadi tuntunan dalam berperilaku di tengah masyarakat yang ditampilkan dalam beberapa tradisi yang tetap dipertahankan hingga sekarang.

Dari segi objek wisata yang ada, Kota Bukittinggi juga banyak memiliki objek wisata yang potensial meliputi wisata alam, wisata sejarah, wisata budaya serta wisata belanja dan konfensi. Berdasarkan data yang diperoleh dari Dinas Pariwisata Kota Bukittinggi tentang banyaknya objek wisata berdasarkan pembagian tersebut yaitu: paling banyak adalah wisata alam sebanyak 6 objek, wisata budaya dan sejarah sebanyak 8 objek, dan wisata buatan manusia (man made) sebanyak 5 objek. Disamping itu masih terdapat wisata lain yang mendukung semua potensi wisata yang ada tersebut yaitu wisata kuliner dengan adanya menu atau makanan yang khas atau spesifik yang hanya bisa ditemui di objek wisata tersebut. Dengan semua potensi pariwisata tersebut, maka Kota Bukittinggi telah membuat perencanaan untuk melakukan penguatan dan pengembangan sektor ekonomi wilayah sebagai salah satu target pembangunan. Penguatan dan pengembangan sektor perekonomian wilayah tersebut mencakup sektor pariwisata sebagai sumber penggerak pertumbuhan dengan memanfaatkan potensi sumber daya alam, sejarah dan kebudayaan/religi yang berkelanjutan. Sektor pariwisata sebagai salah satu sektor dalam perekonomian di Kota Bukittinggi merupakan sektor unggulan yang diharapkan di masa depan akan menjadi leading sector.

Penelitian ini merupakan perluasan dari penelitian terdahulu yang dilakukan oleh Parhusip (2018) yang melakukan kajian kuantitatif dalam menangkap motivasi, karakteristik dan makna berwisata wisatawan milenial yang melakukan kunjungan wisata ke Bali. Tujuan dari dilaksanakannya penelitian adalah untuk menganalisis faktor pendorong dan faktor penarik bagi wisatawan generasi milenial dalam melakukan kunjungan wisata secara berulang ke kota Bukittinggi. Dari hasil penelitian ini diharapkan dapat memberikan kontribusi dan tambahan informasi bagi pihak-pihak yang terkait guna pengembangan dan peningkatan kinerja pariwisata di Kota Bukittinggi.

\subsection{Kerangka Teori}

\section{a. Motivasi Pendorong}

(Crompton, John, (1979) dikutip dari Parhusip(2018)) menyebutkan tujuh motivasi pendorong dan dua motivasi penarik, berikut penjelasan tentang faktor-faktor tersebut. 
1) Escape from a perceived mundane environment (keluar dari lingkungan rutin dan membosankan)

Faktor ini mengacu pada motivasi seseorang yang mengalami kejenuhan dari lingkungan sehari-hari yang mulai dirasakan rutin dan membosankan. Cara mereka untuk menghadapi lingkungan tersebut adalah dengan berlibur dan mencari tempat yang secara fisik dan sosial berbeda dengan lingkungan sehari-hari.

2) Exploration and evaluation of self (eksplorasi dan evaluasi diri) Motivasi untuk berlibur dalam diri seseorang muncul karena ingin mendapatkan kesempatan untuk mengevaluasi dan menemukan sesuatu yang lebih pada diri. Evaluasi dan eksplorasi tentang diri ini tidak dapat didapatkan hanya dengan diam di rumah atau mengunjungi keluarga.

3) Relaxation (relaksasi)

Individu melakukan kegiatan wisata karena ingin melakukan relaksasi keadaan mental ataupun relaksasi keadaan fisik mereka. Relaksasi ini tidak dapat dilakukan dalam kegiatan rutin mereka sehari-hari.

4) Prestige (prestise)

Motivasi untuk berwisata muncul karena menganggap wisata merupakan sebuah simbol gaya hidup kelas atas. Dengan berwisata meningkatkan rasa hormat dan penghargaan dari orang lain.

5) Regression to childhood/ nostalgic (nostalgia)

Motivasi kegiatan muncul karena wisata memungkinkan untuk melakukan sesuatu yang tidak dapat dilakukan dalam kehidupan sehari-hari. Kegiatan tersebut kadang kekanakan, dan lebih pada pengingatan saat remaja atau saat kecil atau nostalgia masa lalu.

6) Enhancement of kinship relationship ( peningkatan hubungan kekeluargaan)

Motivasi berwisata muncul karena ingin meningkatkan hubungan kekeluargaan. Dan peningkatan hubungan kekeluargaan ini sulit dilakukan dalam keseharian mereka karena berbagai kesibukan.

7) Facilitation of social interaction (fasilitasi dari interaksi sosial)

Motivasi untuk wisata muncul karena wisata dianggap sebagai sarana yang memberikan kesempatan bertemu dengan orang-orang baru di berbagai 
tempat. Perjalanan wisata yang dilakukan pun lebih berorientasi pada orang-orang yang ditemui dibandingkan dengan tempat.

\section{b. Motivasi Penarik}

Motivasi penarik (pull) (disebut juga motif budaya, motif yang lebih terkait dengan tempat tujuan wisata dibandingkan dengan status sosial dan psikologis individu) terdapat dua faktor, yaitu:

1) Novelty

Motivasi berwisata yang muncul karena adanya keingintahuan, petualangan, baru dan berbeda. Dan wisata untuk mencari tempat-tempat baru dengan petualangan baru menjadi hal yang menarik. Novel berarti bertemu dengan pengalaman baru tetapi tidak berarti pengetahuan yang baru.

2) Education (pendidikan)

Motivasi wisata dikarenakan adanya minat terhadap pendidikan. Termotivasi untuk mengunjungi tempat-tempat yang memberikan pengetahuan dan pendidikan. Selain itu pendidikan dirasakan sebagai cara untuk mengembangkan diri individu.

Lebih jauh (Crompton, John, (1979) dalam Parhusip(2018)) menyebutkan motivasimotivasi tersebut merupakan kombinasi yang multidimensi, tidak hanya dimaksudkan untuk satu unsur yang eksklusif yang mempengaruhi perilaku seseorang. Orang-orang pergi ke tempat wisata untuk memuaskan motif-motif yang berbeda. Hal ini memungkinkan mereka untuk pergi ke tempat wisata yang berbeda. Sebagai tambahan penulis menyertakan lima faktor motivasi penarik lain dari (Awaritefe, 2004) yang memotivasi seseorang untuk mengunjungi sebuah tempat untuk berwisata, yaitu:

1) Static factor

Faktor-faktor dari tempat wisata yang tidak bisa diubah, contoh: iklim, jarak, sejarah tempat wisata, bentangan alam, dan lain-lain.

2) Dynamic Factor

Faktor-faktor dari tempat wisata yang bisa diubah, contoh: akomodasi termasuk makanan, hiburan, minat pribadi, atmosfir politis, tren pariwisata.

3) Current Decision 
Faktor-faktor yang dapat mempengaruhi keputusan untuk berwisata, contoh: strategi marketing dan harga barang dan jasa di tempat tujuan wisata.

\section{4) Commercial}

Bisnis, contoh: pembelian karya seni, hasil kerajinan tangan.

\section{5) Information/advertisement destination}

Rekomendasi dari teman atau kenalan baru ataupun promosi melalui media.

\section{c. Minat Kunjungan Berulang}

Minat berkunjung ulang merupakan perasaan ingin mengunjungi kembali suatu destinasi wisata di masa mendatang. Wisatawan yang memiliki minat untuk melakukan kunjungan ulang dapat ditandai dengan kemauan untuk meninjau kembali destinasi yang sama di masa depan dan merekomendasikan destinasi kepada orang lain (Alegre, 2009). Liburan yang berulang di tempat yang sama dan menyatakan niat untuk melakukan kunjungan ulang merupakan dua tanda loyalitas terhadap destinasi yang sering diperhitungkan dalam literatur pariwisata (Oppermann dalam (Alegre, 2009) Perasaan ingin mengunjungi kembali suatu destinasi wisata yang sama dapat muncul karena beberapa alasan. Menurut (Moore, 2012), alasan atau faktor utama yang menentukan minat untuk berkunjung kembali ke suatu destinasi adalah kepuasan selama berkunjung, motivasi tertentu dalam memilih tujuan wisata, dan kecintaan wisatawan terhadap destinasi. Kecintaan wisatawan terhadap destinasi dapat diukur dengan jumlah kunjungan berulang yang dilakukan oleh wisatawan tersebut.

\section{d. Generasi Millennial}

Generasi Millennial merupakan sebutan yang diperuntukkan bagi kelompok populasi yang lahir pada tahun 1982 - 2004 (Moore, 2012) Sebutan Generasi Milenial awalnya digunakan di Negara Amerika Serikat yang selanjutnya digunakan pula oleh negaranegara lain di dunia. Berdasarkan data BPS 2015, jumlah milenial di Indonesia telah mencapai 84 juta orang atau 50 persen dari penduduk usia produktif (dalam Kompas.com, 2017 dikutip dari (Isnaini, 2018)). Generasi milenial merupakan generasi yang memiliki tingkat percaya diri yang tinggi dalam hal pengambilan keputusan pembelian (Isnaini, 2018)(Henry and Taylor (2009) dikutip dari (Isnaini, 2018)) Generasi milenial juga memiliki tingkat pendapatan yang tinggi dan telah mulai memanfaatkan kartu kredit dalam melakukan pembelian serta seringkali bertugas dalam melakukan pembelanjaan untuk keluarga (Neuborne dalam Henrie and Taylor, 2009 dikutip dari 
(Isnaini, 2018)). Generasi milenial merupakan pengadopsi awal dari perkembangan teknologi dan inovasi (Kumar dan Lim dalam (Isnaini, 2018). Berdasarkan pada penelitian yang dilakukan Goldman Sachs ( dikutip dari (Isnaini, 2018))ditemukan bahwa generasi milenial lahir ditengah perubahan teknologi, globalisasi dan kekacauan ekonomi dimana hal tersebut menyebabkan terciptanya sekumpulan perilaku yang berbeda pada generasi milenial termasuk perilakunya dalam berbelanja.

\section{e. Kerangka Pikir dan Hipotesis}

Kerangka pemikiran disajikan dalam gambar sebagai berikut:

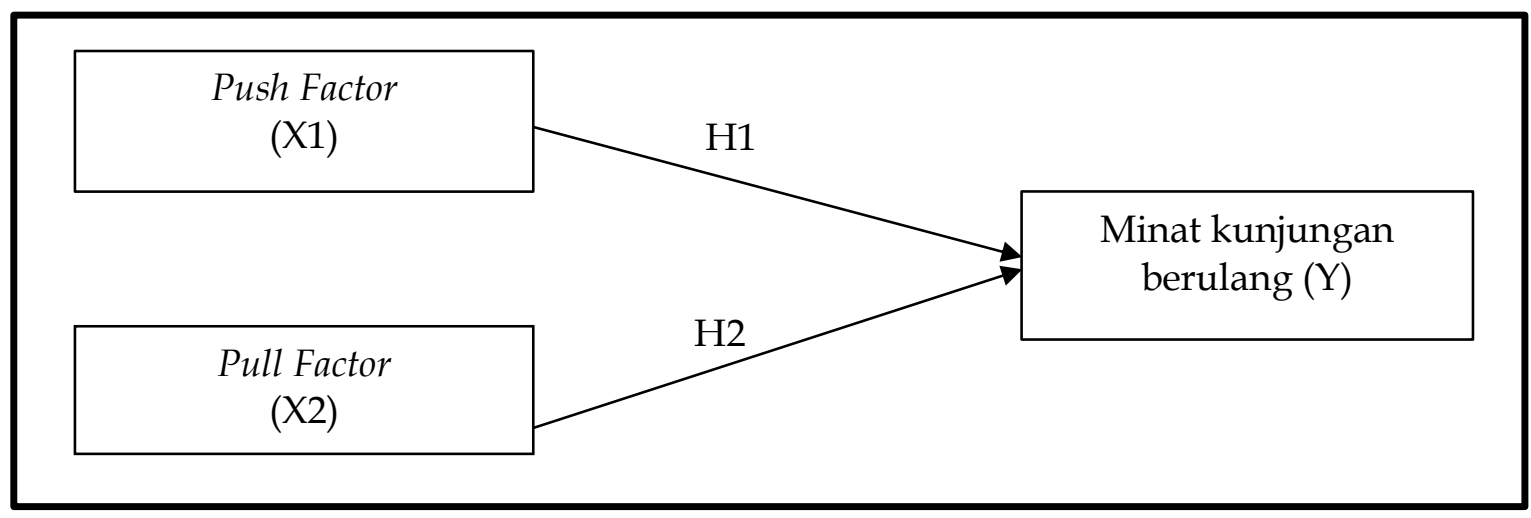

Gambar 1. Kerangka Pikir Analisis Faktor-Faktor yang Mempengaruhi Minat Kunjungan Berulang Wisatawan Milenial Ke Bukittinggi

Berdasarkan kajian teori dan kerangka berfikir maka dapat disusun hipotesis sebagai berikut:

a. Terdapat pengaruh positif dan signifikan antara Push Factor (X1) terhadap Minat Kunjungan berulang (Y)

b. Terdapat pengaruh positif dan signifikan antara Pull Factor (X2) terhadap Minat kunjungan berulang (Y)

\section{METODE PENELITIAN}

\subsection{Jenis Penelitian}

Metode penelitian yang digunakan adalah metode deskriptif kuantitatif, dimana metode tersebut dilakukan melalui pendekatan penelitian yang bersifat obyektif, mencakup pengumpulan dan analisis data kuantitatif serta mengunakan metode pengujian secara statistik. Pendekatan yang digunakan oleh penulis untuk mendapatkan data dilakukan melalui metode survei .Tipe penelitian ini adalah penelitian kuantitatif dengan desain non experimental dimana 
dalam penelitian tidak dilakukan manipulasi terhadap variabel pertama, dilakukan dalam situasi alamiah, bukan dalam situasi terkontrol (Brotowidjojo, 2009).

\subsection{Definisi Operasional}

Tabel 1

Operasional Variabel

\begin{tabular}{|c|c|c|c|}
\hline Variabel & Deskripsi & Jumlah Item & Skala Pengukuran \\
\hline Push & $\begin{array}{l}\text { Adanya faktor } \\
\text { pendorong } \\
\text { mengakibatkan } \\
\text { seseorang ingin } \\
\text { melakukan } \\
\text { perjalanan wisata } \\
\text { dan adanya berbagai } \\
\text { faktor penarik yang } \\
\text { dimiliki oleh DTW } \\
\text { akan menyebabkan } \\
\text { orang tersebut } \\
\text { memilih DTW } \\
\text { tertentu }\end{array}$ & $\begin{array}{l}\text { 1. Melarikan diri (Escape. } \\
\text { 2. Relaksasi (Relaxation) } \\
\text { 3. Bermain (Play) } \\
\text { 4. Memperkuat ikatan } \\
\text { keluarga (Strengthening } \\
\text { family bonds) } \\
\text { 5. Gengsi (Prestige) } \\
\text { 6. Interaksi social (Social } \\
\text { interaction) } \\
\text { 7. percintaan (Romance) } \\
\text { 8. Kesempatan pendidikan } \\
\text { (Educational opportunity) } \\
\text { 9. Pemenuhan diri (Self- } \\
\text { fulfilment) keinginan } \\
\text { 10. Pemenuhan } \\
\text { (Wish-fulfilment) }\end{array}$ & Likert 1 - 5 \\
\hline Pull & $\begin{array}{l}\text { faktor penarik } \\
\text { merupakan }\end{array}$ & $\begin{array}{l}\text { 1. Price } \\
\text { 2. Culture } \\
\text { 3. Natural Environment and } \\
\text { Weather Attraction } \\
\text { 4. Location } \\
\text { 5. Service and Facilities } \\
\text { 6. Entertainment } \\
\text { Relaxation } \\
\text { 7. Safety }\end{array}$ & Likert 1 - 5 \\
\hline $\begin{array}{l}\text { Minat } \\
\text { Berkunjung }\end{array}$ & $\begin{array}{l}\text { Minat berkunjung } \\
\text { Ulang adalah } \\
\text { Keinginan yang kuat } \\
\text { pengunjung } \\
\text { untuk kembali } \\
\text { berkunjung } \\
\text { diwaktu yang akan } \\
\text { datang } \\
\text { sebagai respon } \\
\text { langsung paska } \\
\text { kunjungan pada } \\
\text { waktu tertentu. }\end{array}$ & $\begin{array}{l}\text { 1. Minat untuk berkunjung } \\
\text { kembali. } \\
\text { 2. Memberi rekomendasi } \\
\text { kepada orang lain. } \\
\text { 3. Lebih memilih destinasi } \\
\text { ini dibandingkan } \\
\text { destinasi lainnya }\end{array}$ & Likert 1 - 5 \\
\hline
\end{tabular}




\subsection{Teknik Pengumpulan Data}

Pengumpulan data dilakukan melalui kuesioner, yaitu dengan memberikan daftar pertanyaan (kuesioner) kepada wisatawan milenial yang berkunjung ke Bukittinggi sebagai responden. Pertanyaan-pertanyaan yang diberikan menggunakan skala pengukuran Likert, yaitu skala interval berjenjang dari 1 sampai dengan 5 dengan skor nilai dari sangat tidak setuju sampai dengan sangat setuju untuk pernyataan minat kunjungan berulang, berjenjang 1 sampai 5 dari dengan skor nilai dari sangat tidak setuju sampai dengan sangat setuju untuk pernyataan tentang faktor penarik, dan berjenjang 1 sampai dengan 5 dengan skor nilai dari sangat tidak setuju sampai dengan sangat setuju untuk pernyataan faktor pendorong.

\subsection{Populasi dan Sampel}

Populasi penelitian ini adalah wisatawan milenial yang pernah berkunjung ke Bukittinggi. Pengambilan sampel di lakukan secara nonprobality sampling dan menggunakan metode purposive sampling. Pada penelitian ini kriteria wisatawan milenial yang dimaksudkan adalah orang-orang yang lahir tahun 1980 an hingga 2000 an yang melakukan kegiatan wisata dimana mereka pergi dari lingkungan tempat tinggalnya untuk sementara waktu (lebih dari 24 jam kurang dari 1 tahun) dengan tujuan untuk menikmati daya tarik wisata dimana mereka mengeluarkan uang dan tidak melakukan kegiatan mencari nafkah di tempat tersebut dengan jarak dari tempat tinggal minimal $160 \mathrm{~km}$ dan atau waktu perjalanan yang dibutuhkan untuk pulang pergi lebih dari setengah hari (12 jam). Teknik penentuan sampel adalah purposive sampling dengan jumlah sampel sebanyak 96 dengan mengacu pada Roscoe (dalam (Sugiyono, 2014)) yang menjelaskan bahwa ukuran sampel yang layak dalam penelitian adalah antara 30 sampai dengan 500 adalah tepat untuk kebanyakan penelitian.

\subsection{Teknik Analisis Data}

Berdasarkan permasalahan utama penelitian, tujuan penelitian, hipotesis penelitian, dan kerangka konseptual penelitian, maka metode analisis yang digunakan dalam penelitian ini adalah analisis deskriptif dan teknik analisis model regresi berganda.

a. Analisis deskriptif

yaitu hasil pengolahan data kemudian dideskripsikan dengan tujuan menggunakan push dan pull jawaban responden terhadap variabel penelitian. Metode yang digunakan untuk melakukan analisis deskriptif adalah metode distribusi frekuensi yaitu pengelompokan data menjadi tabulasi data dengan memakai kelas-kelas data dan dikaitkan dengan masing-masing frekuensi. 
b. Regresi Linier Berganda

Analisis regresi linier berganda dalam penelitian ini digunakan untuk mengetahui pengaruh faktor penarik dan faktor pendorong terhadap minat kunjungan berulang wisatawan milenial. Analisis Regresi sederhana digunakan untuk mencari koefisien korelasi antara variabel bebas (variabel X) dengan variabel terikat (variabel Y).

\section{HASIL DAN PEMBAHASAN}

\subsection{Profil Responden}

Secara rinci jumlah kuesioner yang disebarkan serta tingkat pengembaliannya dapat dilihat dari Tabel berikut :

Tabel 2

Tingkat Pengembalian Kuesioner

\begin{tabular}{lc}
\hline \multicolumn{1}{c}{ Keterangan } & Jumlah \\
\hline Kuesioner yang disebarkan & 96 \\
\hline Kuesioner yang kembali & 96 \\
\hline Kuesioner yang dapat diolah & 96 \\
\hline Tingkat pengembalian kuesioner & $100 \%$ \\
\hline Sumber : Data diolah &
\end{tabular}

Adapun profil responden adalah sebagai berikut, berdasarkan jenis kelamin, responden dalam penelitian ini paling banyak adalah laki-laki yaitu sebnayak $60 \%$ dan sisanya sebanyak $40 \%$ adalah perempuan. Selanjutnya ditinjau dari segi usia, responden yang ditemui pada saat melakukan survei berusia antara $15 \mathrm{~s} / \mathrm{d} 21$ tahun. Ditinjau dari segi pekerjaan, data lapangan menunjukan bahwa kebanyakan responden berstatus sebagai pelajar sebanyak $76 \%$. Berdasarkan rata-rata pendapatan dari responden, paling banyak berpenghasilan kecil dari 1 juta per bulan sebanyak 54 \%. Berdasarkan jumlah kunjungan ke Bukittinggi dalam setahun terakhir, jawaban terbanyak dari responden adalah lebih dari 3 kali sebanyak $54 \%$. Terkait pilihan akomodasi selama berkunjung, $54 \%$ menginap di homestay.

\subsection{Analisis Deskriptif}

Dari semua pernyataan pada faktor pendorong yang paling dominan dengan tingkat capaian responden sebesar $86,2 \%$ adalah pernyataan saya ingin menikmati kegembiraan dari wisata ke Bukittinggi yang saya lakukan . Sedangkan dari semua pernyataan pada faktor penarik yang paling dominan dengan tingkat capaian responden mencapai 84,8\% adalah kondisi cuaca pada kawasan Bukittinggi sangat mendukung untuk kawasan pariwisata. Sementara itu dari 
semua pernyataan pada minat kunjung berulang yang paling dominan dengan tingkat capaian responden sebesar 84,8 \% adalah Saya akan memberi rekomendasi kepada orang lain. Analisis regresi digunakan untuk menguji hipotesis tentang pengaruh secara parsial variabel bebas terhadap variabel terikat. Berdasarkan estimasi regresi berganda dengan program SPSS 16 diperoleh hasil sebagai berikut:

Tabel 3

Hasil Estimasi Regresi

Coefficients ${ }^{a}$

\begin{tabular}{|c|c|c|c|c|c|c|c|c|}
\hline \multirow{2}{*}{\multicolumn{2}{|c|}{ Model }} & \multicolumn{2}{|c|}{$\begin{array}{l}\text { Unstandardized } \\
\text { Coefficients }\end{array}$} & \multirow{2}{*}{$\begin{array}{c}\begin{array}{c}\text { Standardized } \\
\text { Coefficients }\end{array} \\
\text { Beta }\end{array}$} & \multirow[b]{2}{*}{$\mathrm{t}$} & \multirow[b]{2}{*}{ Sig. } & \multicolumn{2}{|c|}{ Collinearity Statistics } \\
\hline & & B & Std. Error & & & & Tolerance & VIF \\
\hline \multirow[t]{3}{*}{1} & (Constant) & 1.612 & .815 & & 1.978 & .054 & & \\
\hline & faktor_pendorong & .340 & .154 & .294 & 2.206 & .032 & .992 & 1.008 \\
\hline & faktor_penarik & .319 & .133 & .319 & 2.391 & .021 & .992 & 1.008 \\
\hline
\end{tabular}

a. Dependent Variable: keputusan_pembelian

Sumber: Lampiran output SPSS

Berdasarkan tabel diatas dapat diketahui persamaan regresi yang terbentuk adalah:

$\mathrm{Y}=\mathrm{a}+\mathrm{BX} 1+\mathrm{BX} 2+\mathrm{e}$

$\mathrm{Y}=1.612+0.340 \mathrm{X} 1+0.319 \mathrm{X} 2+\mathrm{e}$

Keterangan:

$\mathrm{Y}=$ Minat Kunjungan Berulang

$\mathrm{A}=$ Constant

$\mathrm{X} 1=$ Push

$\mathrm{X} 2=$ Pull

Dari persamaan tersebut dapat dijelaskan bahwa:

a. Dari persamaan regresi berganda diatas terlihat bahwa nilai konstanta sebesar 0.866 menunjukan bahwa tanpa adapun variabel bebas yaitu Push dan Pull terhadap minat kunjungan berulang adalah positif sebesar 1.162.

b. Nilai koefisien Push (X1) yakni 0.340 dan nilai signifikansinya $0.032<0.05$. Hal ini menunjukan bahwa apabila Push meningkat sebesar satu-satuan maka minat kunjungan berulang (Y) akan meningkat sebesar 0.340 atau 34\% dengan asumsi variabel Pull tetap.

c. Nilai koefisien Pull (X2) yakni 0.319 dan nilai signifikansinya $0.021<0.05$. Hal ini menunjukan bahwa apabila Pull meningkat sebesar satu-satuan maka minat kunjungan berulang (Y) akan meningkat sebesar 0.319 atau 31.9\%. 


\subsection{Pengujian Hipotesis}

\section{a. Uji t ( Uji Hipotesis Secara Parsial )}

Hipotesis dalam penelitian ini diuji kebenarannya dengan menggunakan uji parsial. Pengujian dilakukan dengan melihat taraf signifikansi (pvalue), jika taraf signifikansi yang dihasilkan dari perhitungan di bawah 0,05 maka hipotesis diterima, sebaliknya jika taraf signifikansi hasil hitung lebih besar dari 0,05 maka hipotesis ditolak.

Tabel 4

\section{Hasil Uji t Secara Parsial}

Coefficients ${ }^{\mathrm{a}}$

\begin{tabular}{|c|c|c|c|c|c|c|c|}
\hline \multirow[b]{2}{*}{ Model } & \multicolumn{2}{|c|}{$\begin{array}{l}\text { Unstandardized } \\
\text { Coefficients }\end{array}$} & \multirow{2}{*}{$\begin{array}{c}\begin{array}{c}\text { Standardized } \\
\text { Coefficients }\end{array} \\
\text { Beta }\end{array}$} & \multirow[b]{2}{*}{$\mathrm{t}$} & \multirow[b]{2}{*}{ Sig. } & \multicolumn{2}{|c|}{ Collinearity Statistics } \\
\hline & B & Std. Error & & & & Tolerance & VIF \\
\hline (Constant) & 1.612 & .815 & & 1.978 & .054 & & \\
\hline faktor_pendorong & .340 & .154 & .294 & 2.206 & .032 & .992 & 1.008 \\
\hline faktor_penarik & .319 & .133 & .319 & 2.391 & .021 & .992 & 1.008 \\
\hline
\end{tabular}

a. Dependent Variable: keputusan_pembelian Sumber: Lampiran output SPSS

Berdasarkan tabel di atas, uji t dapat diinterpretasikan sebagai berikut :

1) Hasil pengujian hipotesis Push menunjukkan nilai t hitung sebesar 2.206 dengan taraf signifikansi 0.032. Taraf signifikansi tersebut lebih kecil dari 0.05, yang berarti bahwa hipotesis dalam penelitian ini menolak Ho dan menerima Ha. Dengan demikian dapat berarti bahwa hipotesis $\mathrm{H} 1$.

2) “Faktor Pendorong mempunyai pengaruh positif signifikan terhadap Minat Kunjungan Berulang".

3) Hasil pengujian hipotesis Pull menunjukkan nilai t hitung sebesar 2.391 dengan taraf signifikansi 0.021. Taraf signifikansi tersebut lebih kecil dari 0.05, yang berarti bahwa hipotesis dalam penelitian ini menolak Ho dan menerima Ha. Dengan demikian dapat berarti bahwa hipotesis $\mathrm{H} 2$.

4) "Faktor Penarik mempunyai pengaruh positif signifikan terhadap Minat Kunjungan Berulang".

b. Uji F ( Uji Hipotesis Secara Simultan )

Hipotesis dalam penelitian ini diuji kebenarannya dengan menggunakan uji simultan. Pengujian dilakukan dengan melihat taraf signifikansi (p-value), jika taraf signifikansi 
yang dihasilkan dari perhitungan di bawah 0,05 maka hipotesis diterima, sebaliknya jika taraf signifikansi hasil hitung lebih besar dari 0,05 maka hipotesis ditolak.

Tabel 5

Hasil Uji F Secara Simultan ANOVA $^{b}$

\begin{tabular}{|ll|r|r|r|r|r|}
\hline Model & & Sum of Squares & df & Mean Square & F & \multicolumn{1}{c|}{ Sig. } \\
\hline 1 & Regression & 3.533 & 2 & 1.766 & 4.848 & $.012 \mathrm{a}$ \\
& Residual & 17.124 & 47 & .364 & & \\
& Total & 20.656 & 49 & & & \\
\hline
\end{tabular}

a. Predictors: (Constant), faktor_penarik, faktor_pendorong

b. Dependent Variable: keputusan_pembelian

Sumber: Lampiran output SPSS

Hasil pengujian hipotesis Push dan Pull menunjukkan nilai f hitung sebesar 4.848 dengan taraf signifikansi 0.012. Taraf signifikansi tersebut lebih kecil dari 0.05, yang berarti bahwa hipotesis dalam penelitian ini menolak Ho dan menerima Ha. Dengan demikian dapat disimpulkan bahwa "Faktor Pendorong dan Faktor Penarik mempunyai pengaruh positif signifikan terhadap minat kunjungan berulang"

c. Uji Koefisien Determinasi

Dalam penelitian ini uji koefisien determinasi dari Produk, Harga, Promosi, dan Lokasi adalah sebagai berikut :

Tabel 6

Uji Koefisien Determinasi

Model Summaryb

\begin{tabular}{|c|c|c|c|c|c|c|c|c|c|}
\hline \multirow[b]{2}{*}{$\begin{array}{l}\text { Mode } \\
1\end{array}$} & \multirow[b]{2}{*}{$\mathrm{R}$} & \multirow[b]{2}{*}{$\begin{array}{c}\mathrm{R} \\
\text { Square }\end{array}$} & \multirow[b]{2}{*}{$\begin{array}{l}\text { Adjusted } \\
\text { R Square }\end{array}$} & \multirow[b]{2}{*}{$\begin{array}{l}\text { Std. Error of } \\
\text { the Estimate }\end{array}$} & \multicolumn{5}{|c|}{ Change Statistics } \\
\hline & & & & & $\begin{array}{c}\mathrm{R} \\
\text { Square } \\
\text { Change }\end{array}$ & $\begin{array}{c}\text { F } \\
\text { Change }\end{array}$ & df1 & $\mathrm{df} 2$ & $\begin{array}{l}\text { Sig. F } \\
\text { Change }\end{array}$ \\
\hline 1 & $.414^{\mathrm{a}}$ & .171 & .136 & .60360 & .171 & 4.848 & 2 & 47 & .012 \\
\hline
\end{tabular}

a. Predictors: (Constant), faktor_penarik, faktor_pendorong

b. Dependent Variable: keputusan_pembelian

Sumber: Lampiran output SPSS

Dari tabel diatas menunjukkan besar pengaruhnya Push dan Pull terhadap Keputusan Berkunjung adalah sebesar 0.136 atau 13.6 \%. Hal ini menunjukkan bahwa Push dan Pull mampu menjelaskan pengaruhnya terhadap Minat Kunjungan Berulang sebesar 13,6 \%, 
sedangkan sisanya sebesar 86,4 \% dijelaskan oleh faktor-faktor lain yang tidak digunakan dalam model regresi penelitian ini

\section{KESIMPULAN DAN IMPLIKASI}

\subsection{Kesimpulan}

Berdasarkan hasil pembahasan diatas maka dapat diambil kesimpulan sebagai berikut:

a. Berdasarkan masing-masing pernyataan pada variabel faktor pendorong, pernyataan yang paling dominan dipilih oleh wisatwan milenial adalah pernyataan nomor 3 dengan tingkat capaian responden $86.2 \%$ yaitu bermain (play). Sedangkan pernyataan yang paling kecil adalah pernyataan nomor 5 yaitu prestige (gengsi) dengan tingkat capaian responden $48 \%$.

b. Berdasarkan masing-masing pernyataan pada variabel faktor penarik, pernyataan yang paling dominan dipilih oleh wisatawan milenial adalah pernyataan nomor 3 yaitu natural environment and weather attraction dengan tingkat capaian responden $84.8 \%$. sedangkan pernyataan yang paling kecil adalah pernyataan nomor 5 yaitu service and facilities dengan tingkat capaian responden $72 \%$.

c. Berdasarkan masing-masing pernyataan pada variabel minat kunjungan berulang, pernyataan yang paling dominan adalah pernyataan nomor 3 yaitu pernyataan Lebih memilih destinasi ini dibandingkan destinasi lainnya dengan tingkat capaian responden $84.8 \%$. sedangkan pernyataan yang paling kecil adalah pernyataan nomor 1 yaitu pernyataan Minat untuk berkunjung kembali dengan tingkat capaian responden $74.8 \%$.

d. Hasil pengujian hipotesis Push menunjukkan nilai t hitung sebesar 2.206 dengan taraf signifikansi 0.032. Taraf signifikansi tersebut lebih kecil dari 0.05, yang berarti bahwa hipotesis dalam penelitian ini menolak Ho dan menerima Ha. Dengan demikian dapat berarti bahwa hipotesis H1 "Push mempunyai pengaruh signifikan terhadap Keputusan Berkunjung". Hal ini berarti Push yang akan mempengaruhi Keputusan Berkunjung Berulang.

e. Hasil pengujian hipotesis Pull menunjukkan nilai t hitung sebesar 2.391 dengan taraf signifikansi 0.021. Taraf signifikansi tersebut lebih kecil dari 0.05, yang berarti bahwa hipotesis dalam penelitian ini menolak Ho dan menerima Ha. Dengan demikian dapat berarti bahwa hipotesis H2 "Pull mempunyai pengaruh signifikan terhadap Keputusan 
Berkunjung". Hal ini berarti Pull yang akan mempengaruhi Keputusan Berkunjung berulang di masa yang akan datang.

f. Hasil pengujian hipotesis Push dan Pull terhadap Keputusan Berkunjung adalah sebesar F hitung 4.848 dengan taraf signifikansi 0,012 yang berarti bahwa hipotesis dalam penelitian ini menolak Ho dan menerima Ha. Dengan demikian dapat berarti bahwa hipotesis H3 "Push dan Pull Motivation mempunyai pengaruh signifikan terhadap Keputusan Berkunjung".

g. Hasil penelitian menunjukkan besar pengaruhnya Push dan Pull terhadap Keputusan Berkunjung adalah sebesar 0.136 atau 13.6 \%. Hal ini menunjukkan bahwa Push dan Pull mampu menjelaskan pengaruhnya terhadap Keputusan Berkunjung sebesar 13,6 \%, sedangkan sisanya sebesar 86,4 \% dijelaskan oleh faktor-faktor lain yang tidak digunakan dalam model regresi penelitian ini.

\subsection{Implikasi}

Berdasarkan perumusan masalah yang telah dibahas pada bab sebelumnya maka peneliti menyarankan beberapa hal sebagai berikut:

a. Keinginan untuk bermain adalah indikator utama yang dicari oleh wisatawan milenial (push motivation) di Kota Bukittinggi dan dapat meningkatkan kunjungan berulang dimasa yang akan datang. Oleh karena itu bagi Kota Bukittinggi jika ingin wisatawan milenial melakukan kunjungan berulang di masa yang akan datang maka seharusnya setiap aspek daya tarik (atraksi) harus berbasiskan pengalaman bermain yang melibatkan wisatawan millennial secara langsung. Salah satu bentuk atraksi adalah pelaksanaan event pariwisata dalam berbagai konsep yang berbasiskan pengalaman keterlibatan langsung dari wisatawan milenial seperti salah satu contohnya adalah event budaya lokal yang melibatkan wisatawan secara penuh bukan hanya sebagai penonton tapi lebih sebagai pelaku.

b. Natural environment adalah faktor utama yang dapat meningkatkan kunjungan berulang wisatawan milenial di masa yang akan datang selain weather attraction yang memang dimiliki oleh Kota Bukittinggi. Terkenal dengan kota yang sejuk dan alam yang indah sudah merupakan karunia yang diberikan oleh Tuhan YME kepada Kota Bukittinggi. Karunia ini haruslah tetap dijaga dengan mengembangkan konsep pariwisata berkelanjutan untuk semua lini masyarakat Kota Bukittinggi. Regulasi yang jelas dan 
komitmen yang kuat dari semua stakeholder harus tetap dijaga untuk mempertahankan keindahan alam dan cuaca yang sejuk di Kota Bukittinggi.

c. Keterlibatan masyarakat dalam mengembangkan pariwisata harus ditingkatkan. Pemerintahan daerah dapat memberikan sosialisasi dan pelatihan kepada masyarakat setempat tentang pentingnya pariwisata bagi masyarakat. Selain itu dengan membentuk kelompok sadar wisata di daerah tujuan wisata tentunya juga dapat meningkatkan keterlibatan masyarakat dalam meningkatkan kinerja pariwisata di Kota Bukittinggi. Perasaan aman menjadi salah satu indikator utama dalam meningkatkan arus kunjungan berulang dari sisi milenial.

d. Memperkuat atraksi, aksesibiliti dan akomodasi di daerah tujuan wisata. Pemda harus dapat menyikapi kebutuhan wisatawan terhadap kemudahan akses untuk memasuki daerah wisata selain juga tersedianya akomodasi yang affordable namun bersih dan nyaman.

\section{REFERENSI}

Alegre, Joaquin and Cladera, Magdalena. (2009), "Anlysing The Effect of Satisfaction and Previous Visits on Tourist Intentions to Return", European Journal of Marketing, Vol.43, No. (5/6), pp. 670-685.

Cohen, E. (2003), "Backpacking: Diversity and Change", Journal of Tourism and Cultural Change, Vol. 1, No. 2, pp. 95-110.

Desforges, L. (2000), "Traveling the World: Identity and Travel Biography", Annuals of Tourism Research, Vol. 27, No. 4, pp. 926-945.

Isnaini dan Abdillah (2018), "Pengaruh Citra Merek Destinasi terhadap Keputusan Berkunjung dan Kepuasan berkunjung serta Dampaknya terhadap Minat Kunjungan Ulang", Jurnal Administrasi dan Bisnis, Vol. 55, No. 2, hal. 122-129.

Moore, Marguerite. (2012), "Interactive Media Usageamong Millennial Consumers", Journal of Consumer Marketing, Vol. 29, No. 6, pp. 436-44.

Mukayat D. Brotowidjojo. (2009), "Metodologi Penelitian dan Penulisan Karangan Ilmiah", Yogyakarta: Liberty, hal. 69.

Parhusip, Nina. (2018), "Wisatawan Milenial Di Bali (Karakteristik, Motivasi, dan Makna Berwisata", Jurnal Destinasi Pariwisata, Vol. 6, No. 2, hal. 299-303. 
Andalas Management Review, Vol. 4 No. 1, 2020

Sugiyono. (2014), Metode Peneliatian Kuantitatif Kualitatif dan R\&D, Bandung: Alfabeta.

Wulan, K. M. dan Ninik, F. R. (2017), "Generasi Y Doyan Pindah-Pindah Kerja" available at : http://nasional.kompas.com/read/2017/02/11/17141441/generasi.y.doyan.pindahpinda h.kerja.simak.kompas.minggu.11.2.2017 (24 Januari 2020). 